\title{
Hubungan Stres dengan Stomatitis Aftosa Rekuren pada Mahasiswa Program Studi Pendidikan Dokter Gigi Universitas Sam Ratulangi
}

\author{
${ }^{1}$ Yosef P. Wowor \\ ${ }^{2}$ Herdy Munayang \\ ${ }^{1}$ Aurelia Supit \\ ${ }^{1}$ Program Studi Pendidikan Dokter Gigi Fakultas Kedokteran \\ ${ }^{2}$ Bagian Ilmu Psikiatri Fakultas Kedokteran \\ Universitas Sam Ratulangi Manado \\ Email: pwowor59@gmail.com
}

\begin{abstract}
Recurrent aphtosa stomatitis (RAS) or aphthous ulcer on the oral mucosa can be triggered by several predisposing factors, inter alia stress. This study was aimed to determine the relationship between stress and RAS among students of Dentistry Study Program of Sam Ratulangi University. This was an analytical study with a cross sectional design. Samples were obtained by using total sampling method. There were 64 students as respondents. This study was conducted by examination of the oral cavity of the respondents, and filling the SAR question list as well as the perceived stress scale (PSS) questionnaire. The results showed that $48 \%$ of respondents experienced RAS and $51.6 \%$ did not. Moreover, $25 \%$ of respondents experienced mild stress, $45.3 \%$ moderate stress, and $29.7 \%$ severe stress. The chi-square test showed a p-value of 0.000 . In conlusion, there was a significant relationship between stress and recurrent aphthous stomatitis among students at Dentistry Study Program of Sam Ratulangi University.
\end{abstract}

Keywords: recurrent aphthous stomatitis, stress level

\begin{abstract}
Abstrak: Stomatitis aftosa rekuren (sar) atau ulkus aftosa pada mukosa mulut yang bersifat rekuren dapat dipicu oleh beberapa faktor predisposisi salah satunya stres. Tujuan penelitian ini untuk mengetahui hubungan stres dengan stomatitis aftosa rekuren pada mahasiswa Program Studi Pendidikan Dokter Gigi Universitas Sam Ratulangi. Jenis penelitian ialah analitik dengan desain potong lintang. Pengambilan sampel menggunakan metode total sampling seluruh mahasiswa di Program Studi. Terdapat total 64 mahasiswa sebagai responden penelitian. Penelitian dilakukan melalui pemeriksaan rongga mulut, serta pengisian daftar pertanyaan SAR dan kuesioner perceived stress scale (PSS). Hasil penelitian menunjukkan bahwa $48 \%$ responden mengalami SAR dan $51,6 \%$ yang tidak mengalami SAR. Selain itu, 25\% responden mengalami tingkat stres ringan, $45,3 \%$ sedang, dan $29,7 \%$ berat. Hasil analisis uji chi-square menunjukkan nilai $\mathrm{p}=0,000$. Simpulan penelitian ini ialah terdapat hubungan bermakna antara stres dengan stomatitis aftosa rekuren pada mahasiswa Program Studi Pendidikan Dokter Gigi Universitas Sam Ratulangi.
\end{abstract}

Kata kunci: stomatitis aftosa rekuren, tingkat stress

Masalah kesehatan gigi dan mulut merupakan masalah yang tersebar luas di masyarakat Indonesia. Salah satu penyakit gigi dan mulut yang sering menyerang rongga mulut yaitu stomatitis aftosa rekuren (SAR) atau ulkus aftosa pada mukosa mulut yang bersifat rekuren atau berulang. ${ }^{1}$ Prevalensi SAR pada populasi dunia berkisar 20\%. ${ }^{2}$ Berdasarkan hasil riset kesehatan dasar (Riskesdas) tahun 
2018, prevalensi nasional penyakit gigi dan mulut di Indonesia yaitu sebesar 57,6\%. Penyakit gigi dan mulut yang sering dialami masyarakat Indonesia salah satunya yaitu SAR dengan prevalensi nasional yaitu sebesar $8,0 \%$ dan untuk provinsi Sulawesi Utara sebesar $10,4 \% .^{3}$

Stomatitis aftosa rekuren merupakan penyakit yang relatif ringan karena tidak bersifat membahayakan jiwa dan tidak menular, namun bagi sebagian orang SAR dapat menimbulkan rasa tidak nyaman karena fungsi pengunyahan, fungsi penelanan, dan fungsi berbicaranya terganggu. ${ }^{4}$ Etiologi SAR yang pasti hingga saat ini belum diketahui dengan jelas, tetapi menurut penelitian sebelumnya yang dilakukan oleh Sugaya di Brazil menunjukkan bahwa gangguan psikologis seperti stres dapat berperan terhadap muncul SAR ${ }^{5} \mathrm{Hal}$ ini juga didukung oleh hasil penelitian yang dilakukan Tangkilisan ${ }^{6}$ di Manado mengenai gambaran stres pada mahasiswa pendidikan profesi Program Studi Pendidikan Dokter Gigi (PSPDG) Fakultas Kedokteran Universitas Sam Ratulangi, menunjukan bahwa sebesar 59,7\% mahasiswa dengan pengalaman SAR memiliki tingkat stres yang tinggi.

Berdasarkan survei awal, diketahui mahasiswa program studi pendidikan dokter gigi universitas sam ratulangi (PSPDG) cenderung menglami stres karena memiliki beban studi yang tinggi, jadwal kuliah padat, dan tekanan prestasi. Selain itu stres yang dialami mahasiswa juga yaitu masa penyesuaian diri dengan lingkungan baru sehingga stres yang terjadi dapat memicu munculnya SAR dalam rongga mulut. Berdasarkan latar belakang di atas peneliti tertarik untuk melakukan penelitian mengenai hubungan stres dengan stomatitis aftosa rekuren pada mahasiswa PSPDG Universitas Sam Ratulangi.

\section{HASIL PENELITIAN}

Jenis penelitian ini ialah penelitian analitik dengan desain potong lintang. Penelitian dilaksanakan di PSPDG Universitas Sam Ratulangi pada bulan mei 2019.

Populasi penelitian yaitu seluruh mahasiswa angkatan 2015-2018 yang ada di PSPDG Unsrat berjumlah 89 orang. Teknik pengambilan sampel yang digunakan dalam penelitian ini ialah metode total sampling dimana peneliti mengambil seluruh mahasiswa angkatan 2015-2018 untuk dijadikan responden penelitian yang memenuhi kriteria inklusi.

Pengumpulan data dilakukan pada mahasiswa PSPDG Unsrat. Peneliti sebelumnya memberi lembar persetujuan (informed consent) kepada calon responden pada hari penelitian kemudian calon responden yang setuju menjadi subyek penelitian mengisi (informed consent) dan langsung dikumpulkan pada hari yang sama. Semua responden dilakukan pemeriksaan mulut sehingga dapat dilihat ada tidaknya SAR dalam rongga mulut, kemudian responden yang mengalami SAR diwawancarai dengan daftar pertanyaan SAR dan dikumpulkan pada saat itu juga.

Kuesioner untuk menilai tingkat stres yang dialami seseorang dilakukan dengan menyajikan kuesioner perceived stress scale (PSS) yang terdiri dari sepuluh pertanyaan dengan empat pilihan dan dijawab dengan mencentang $(\sqrt{ })$ jawaban yang tepat, setelah selesai dikumpulkan pada saat itu juga.

Data yang diperoleh kemudian dianalisis untuk mengetahui hubungan stres dengan SAR pada subyek menggunakan program aplikasi SPSS 20. Analisis univariat digunakan untuk memperoleh gambaran pada masing-masing variabel dan disajikan dalam bentuk tabel. Analisis bivariat digunakan untuk mengetahui hubungan antara variabel dan dilakukan uji statistik chi-square dengan menggunakan derajat kepercayaan $95 \%(\alpha=0,05)$.

\section{HASIL PENELITIAN}

Responden dalam penelitian ini yaitu seluruh mahasiswa PSPDGangkatan 2015, 2016, 2017, 2018 dengan jumlah mahasiswa 89 orang. Yang terlibat dalam pengisian kuesioner setelah diseleksi berdasarkan kriteria inklusi dan ekslusi ialah sebanyak 64 responden.

Berdasarkan jenis kelamin didapatkan 
sebagian besar responden berjenis kelamin perempuan yaitu 48 orang $(75 \%)$ sedangkan 8 responden $(25 \%)$ berjenis kelamin laki-laki.

Tabel 1 memperlihatkan distribusi responden berdasarkan usia. Responden yang lebih banyak berusia 21 tahun $(28,2 \%)$ dan yang paling sedikit responden berusia 22 tahun $(3,2 \%)$.

Tabel 1. Distribusi responden berdasarkan usia

\begin{tabular}{ccc}
\hline Usia & $\mathbf{N}$ & \% \\
\hline 18 & 15 & 23,4 \\
19 & 14 & 21,8 \\
20 & 15 & 23,4 \\
21 & 18 & 28,2 \\
22 & 2 & 3,2 \\
Total & 64 & 100 \\
\hline
\end{tabular}

Hasil pemeriksaan SAR dilakukan dengan menggunakan kaca mulut, dan alat penerang. Pemeriksaan dilakukan dengan cara responden disuruh membuka mulut sehingga dapat dilihat ada tidaknya SAR pada rongga mulut. Responden yang terkena SAR diberikan daftar pertanyaan yang ada melalui wawancara. Hasil pemeriksaan mulut mendapatkan responden yang mengalami SAR sebanyak 31 orang $(48,4 \%)$ sedangkan yang tidak mengalami SAR yaitu 33 orang $(51,6 \%)$ dari 64 responden. Seluruh responden tergolong dalam klasifikasi SAR minor (ringan), tidak ada responden yang menderita SAR mayor atau herpetiformis.

Pengukuran tingkat stres dilakukan dengan memberikan kuesioner PSS yaitu alat ukur psikologis yang paling banyak digunakan untuk mengukur sejauh mana situasi dalam kehidupan sesorang yang dinilai sebagai stres. Hasil ukurnya dikategorikan menjadi tiga kategori yaitu ringan dengan total skor 0-13, sedang dengan total skor 14-26, dan berat dengan total skor 27-40.

Tabel 2 menunjukkan distribusi responden berdasarkan tingkat stres. Respoden yang memiliki memiliki tingkat stres paling tinggi yaitu tingkat stres sedang $(58,1 \%)$ dan jumlah responden yang memiliki tingkat stres terendah yaitu tingkat stres ringan $(41,9 \%)$.

Tabel 2. Distribusi responden berdasarkan tingkat stress

\begin{tabular}{cll}
\hline Tingkat stres & $\mathbf{N}$ & $\mathbf{\%}$ \\
\hline Ringan & 16 & 25,0 \\
Sedang & 29 & 45,3 \\
Berat & 19 & 29,7 \\
Total & 64 & 100 \\
\hline
\end{tabular}

Tabel 3 menampilkan hubungan stres dengan SAR pada mahasiswa PSPDG Unsrat. Berdasarkan hasil analisis uji chisquare didapatkan nilai $\mathrm{p}=0,000$ yang menunjukkan adanya hubungan stres dengan stomatitis aftosa rekuren pada responden.

Tabel 3. Hubungan stres dengan stomatitis aftosa rekuren pada responden

\begin{tabular}{cccccccc}
\hline \multirow{2}{*}{ Stres } & \multicolumn{2}{c}{ Ya } & \multicolumn{2}{c}{ SAR } & \multicolumn{2}{c}{ Tidak } & \multicolumn{2}{c}{ Total } & \multirow{2}{*}{ p } \\
& $\mathrm{N}$ & $\%$ & $\mathrm{~N}$ & $\%$ & $\mathrm{~N}$ & $\%$ & \\
\cline { 1 - 7 } Ringan & 0 & 0 & 16 & 25 & 16 & 25 & 0.000 \\
Sedang & 18 & 28,2 & 11 & 17,2 & 29 & 45,4 & \\
Berat & 13 & 20,3 & 6 & 9,3 & 19 & 29,6 & \\
Total & 31 & 48,5 & 33 & 51,5 & 64 & 100 & \\
\hline
\end{tabular}

\section{BAHASAN}

Responden yang terlibat dalam penelitian ini berjumlah 31 orang. Berdasarkan karakteristik sebagian besar responden yang terlibat pada penelitian ini berjenis kelamin perempuan yaitu berjumlah $74,2 \%$, 
sedangkan responden yang berjenis kelamin laki-laki berjumlah 25,8\%. Dari 31 responden penelitian ini responden yang paling banyak berusia 21 tahun $(35,4 \%)$ dan yang paling sedikit berusia 22 tahun $(6,4 \%)$.

Hasil penelitian mengenai hubungan tingkat stres dengan stomatitis aftosa pada mahasiswa PSPDG Unsrat, menunjukkan bahwa tingkat stres paling tinggi terjadi pada stres kategori sedang. Hal ini menggambarkan bahwa kecenderangan stres pada mahasiswa PSPDG Unsrat cukup besar. Tingginya tingkat stres yang dirasakan di kalangan mahasiwa pada penelitian ini selaras dengan penelitian yang dilakukan oleh Gallo et $\mathrm{al}^{5}$ di Brazil yang menyatakan bahwa tingginya tingkat stres yang dirasakan di kalangan mahasiswa kedokeran gigi sering dikaitkan dengan tekanan psikologis dan kelelahan emosi. Hasil penelitian ini juga didukung oleh penelitian Tangkilisan ${ }^{6}$ di Manado yang menyatakan bahwa pada mahasiswa pendidikan profesi dokter gigi RSGM Unsrat memiliki tingkat stres yang tinggi. Penelitian serupa juga dilakukan oleh Singh di India yang menyatakan bahwa sebagian mahasiswa tidak cukup percaya diri untuk mengatasi masalah pribadi mereka dan hanya sedikit yang mampu mengatasi stres dengan baik, sedangkan yang lain merasa kesulitan mengatasi stres mereka dan menumpuk stresnya sehingga mereka tidak dapat mengatasinya. Hal ini mencerminkan ketidakdewasaan psikologis dan emosional mereka. ${ }^{7}$

Hasil penelitian ini menunjukkan bahwa responden yang tidak terkena SAR lebih banyak daripada responden yang terkena SAR. Literatur menyatakan bahwa prevelensi SAR tergantung pada daerah atau tempat yang diteliti. ${ }^{2}$ Hal ini terbukti pada penelitian yang dilakukan oleh Sulistiani ${ }^{4}$ di Jember yang menyatakan bahwa prevelensi SAR pada pasien RSGM FKG Universitas Jember sebesar 14\%. Penelitian serupa juga dilakukan oleh Banuaera di Medan ${ }^{7}$ menunjukkan bahwa prevelensi angka SAR pada mahasiswa USU sebesar $64,3 \%$. Hasil penelitian yang dilakukan oleh Darmanta ${ }^{8}$ di Manado menunjukkan angka prevelensi SAR pada mahasiswa PSPDG Unsrat sebesar 68,2\%. Selain adanya perbedaan daerah atau tempat yang diteliti, jumlah populasi dan jangka waktu yang digunakan dalam penelitian, serta metode penelitian yang digunakan dapat menyebabkan adanya angka prevalensi yang bervariasi tersebut.

Terdapat tiga tipe SAR yang diketahui hingga saat ini dengan gambaran klinis yang khas, yaitu SAR minor, mayor, dan herpetiformis. ${ }^{9}$ Hasil penelitian mengenai klasifikasi SAR menunjukkan bahwa responden hanya mengalami SAR minor sebesar $100 \%$. Data tersebut menunjukkan bahwa SAR minor merupakan kasus yang paling banyak terjadi dibandingkan dengan kasus SAR mayor dan SAR herpetisformis. Hal ini sesuai dengan karakteristik SAR minor, yaitu muncul pertama kali pada dekade $2-3 .{ }^{10}$ Dalam penelitian ini responden berusia 18-22 tahun. Hal ini selaras dengan penelitian Wulandari dan Setyawati ${ }^{11}$ di Jakarta melaporkan bahwa pada tahun 2009 SAR minor merupakan kasus yang paling banyak terjadi dibandingkan dengan SAR mayor dan SAR hipertisformis.

Penelitian yang dilakukan pada 64 responden di PSPDG Unsrat dianalisis menggunakan uji statistik chi square. Berdasarkan hasil uji chi-square didapatkan nilai $\mathrm{p}=0,000$ yang menunjukkan terdapat hubungan stres dengan stomatitis aftosa rekuren pada mahasiswa PSPDG Unsrat. Hasil penelitian ini didukung oleh penelitian Gallo et $\mathrm{al}^{5}$ di Brazil yang menyatakan bahwa stres psikologis menginduksi aktivitas imunoregulasi dengan meningkatkan jumlah leukosit di tempat peradangan yang merupakan faktor penyebab munculnya SAR. Tingkat stres memiliki hubungan positif dengan SAR, yaitu stres dapat memicu terjadinya SAR dan biasanya diamati selama situasi penuh tekanan seperti saat periode ujian, saat perawatan gigi, saat terpapar oleh lingkungan baru, serta saat periode perubahan nyata dalam kehidupan. ${ }^{5}$ Hal ini didukung oleh penelitian George dan Joseph $^{12}$ di India yang menyatakan bahwa 
antara stres dan sar memiliki hubungan bermakna.

\section{SIMPULAN}

Berdasarkan hasil penelitian ini dapat disimpulkan bahwa terdapat hubungan bermakna antara stres dan stomatitis aftosa rekuren pada mahasiswa PSPDG.

Diharapkan adanya penelitian lanjut mengenai hubungan SAR dengan faktor predisposisi lainnya, dengan populasi yang lebih beragam, waktu penelitian yang lebih panjang, dan uji statistik lebih lanjut, sehingga hasilnya dapat digunakan secara umum untuk peningkatan derajat kesehatan gigi dan mulut khusunya yang berhubungan dengan penyakit gigi dan mulut.

\section{DAFTAR PUSTAKA}

1. Lynch MA, Brightman AJ, Grenberg MS. Ilmu Penyakit Mulut Diagnosis dan Terapi (8th ed). Jakarta: Binarupa Aksara, 1994; p. 194.

2. Neville BW, Damm DD, Allen CM, et al. Oral and Maxillofacial Pathology (3rd ed). Philadelphia: Elsevier-Sunders, 2009; p. 285-90.

3. Badan Penelitian dan Pengembangan Kesehatan. Hasil Utama Riskesdas 2018. Jakarta: Kemenkes RI, 2013; p. 110-1.

4. Sulistiani A. Prevalensi dan distribusi penderita stomatitis aftosa rekuren (SAR) di Klinik Penyakit Mulut RSGM FKG Universitas Jember. J UNEJ. 2014;5(1):170-1.

5. Gallo CB, Mimura MAM, Sugaya NN.
Psychological stress and recurrent aphthous stomatitis. J Univesidade De Sao Paulo. 2009;64(6):645-8.

6. Tangkilisan V. Gambaran stress pada mahasiswa Pendidikan Profesi Program Studi Kedokteran Gigi Fakultas Kedokteran Universitas Sam Ratulangi yang memiliki pengalaman stomatitis aftosa rekuren. eG. 2013;1(2).

7. Banuarea TP. Prevalensi terjadinya stomatitis aftosa rekuren (SAR) pada mahasiswa Universitas Sumatera Utara yang berpengalaman SAR [Skripsi]. Medan: Fakultas Kedokteran Gigi Universitas Sumatera Utara; 2009.

8. Darmanta AY. Angka kejadian lesi yang diduga sebagai stomatitis aftosa rekuren pada mahasiswa Program Studi Kedokteran Gigi Fakultas Kedokteran Universitas Sam Ratulangi. eG. 2013; 1(2).

9. Grennberg MS, Glick M. Burket's Oral Medicine (8th ed). Hamilton: Decker Inc, 2008; 57.

10. Burket L. Oral Medicine, Diagnosis and Treatment (10th ed). Philadelphia: Lippincortt Company, 2003; p. 63-7.

11. Wulandar EAT, Setyawati T. Tatalaksana SAR minor untuk mengurangi rekurensi dan keparahan. Indonesia Jurnal of Dentistry. 2009;15(2):147-54.

12. George S, Joseph BB. A study on aphthous ulcer and its association with stress among medical students of an Indian Medical Institution. IJCMR. 2009; 64(7):645-8. 